\title{
Combination of Leunca Herb Ethanolic Extract and Doxorubicin Suppresses HeLa Cells' Growth
}

\author{
Sarmoko $^{1,2}$, Dyaningtyas D.P. Putri ${ }^{2}$, Endah Puspitasari ${ }^{2,3}$, Anindyajati ${ }^{2}$, \\ Edy Meiyanto $^{2 *}$ \\ ${ }^{1}$ Department of Pharmacy, Faculty of Medicine and Health Sciences, Universitas Jenderal Soedirman, Purowokerto, \\ Jawa Tengah \\ ${ }^{2}$ Cancer Chemoprevention Research Center, Faculty of Pharmacy, Universitas Gadjah Mada, Yogyakarta \\ ${ }^{3}$ Faculty of Pharmacy, Universitas Jember, Jember, Jawa Timur
}

\begin{abstract}
Leunca (Solanum nigrum L.)ethanolic extractshowedcytotoxic activity on several cancer cell lines (HepG2, HT-29) and showed anti-proliferative activityon MCF-7 cells. Its application as a combinationagent in chemotherapy will increase the effectivity and reduce the toxicity of chemotherapy. We predict that application of combinatorial chemotherapy in cancer treatment will be more effective and less toxic compared to single treatment. Our research aims to investigate the cytotoxic activitiy of leunca herbs ethanolic extract alone and in combination with doxorubicin on HeLa cell line. MTT assay was conducted to measure the growth inhibitory effect of leunca herbs ethanolic extract and combinatorial treatments. Leunca herb ethanolic extract $(5,50,250 \mu \mathrm{g} / \mathrm{ml})$ increased the cytotoxic effect of doxorubicin compared to doxorubicin alone. The strongest cytotoxic activity resulted from the combination of $250 \mu \mathrm{g} / \mathrm{ml}$ leunca herbs ethanolic extract and $250 \mathrm{nM}$ doxorubicin. Based on our results, leunca herbs ethanolic extract is a potential chemopreventive agent, while its molecular mechanism needs to be explored.
\end{abstract}

Keywords: Leunca herbs ethanolic extract, doxorubicin, HeLa, MTT assay

\section{INTRODUCTION}

Combination chemotherapy

(cochemotherapy) has been used widely due to tumor cell heterogeneity, drug resistance, and the increasing successfulness in the clinic (Kufe et al., 2003). Chemoprevention agents originated from nature seems to be a promising candidate for cochemotherapeutic agents. Leunca (Solanum nigrum L.) is one of the herbs having this potency. It has solanine, solasodine, and solamargine (Everist, 1974; Weller and Phipps, 1979).

Solanine is able to induce apoptosis in HepG 2 cells mediated by the inhibition of Bcl-2 expression (Ji et al., 2008). While $\beta$-2-solamargine is cytotoxic on some cancer types, e.g.: colon cancer (HT-29 and HCT-15), prostate cancer (LNCaP and PC-3), and breast cancer (T47D and MDA-MB-231) (Hu et al., 1999). Solamargine could also induce apoptosis through mitochondrial pathway (Liang et al., 2008) and modulate the expressions of TNFRs and Bcl-2 on H441, H520, H661, and H69 human lung cancer cells (Liu et al.,
2004). Thus, its potential as co-chemotherapeutic agent needs to be explored.

Leunca herb ethanolic extract has been found to have synergistic effect when combined with doxorubicin on T47D cells (Anindyajati et $a l ., 2010)$ as well as with cisplatin on HeLa cells (Istiaji et al., 2010). This study aimed to observe the effect of leunca's ethanolic extract (LEE) application on the cytotoxicity performed by doxorubicin, analyzed by MTT assay.

The data could complete the cochemotherapeutic potency of leunca. Combinatorial treatment of doxorubicin and LEE were applied in order to increase the cytotoxicity of doxorubicin on HeLa cells, allowing the use of lower dose of the chemotherapeutic agent giving less toxicity on normal tissues.

$\overline{\text { *Corresponding author e-mail : meiyan_e@ugm.ac.id }}$ 


\section{MATERIALS AND METHODS}

\section{Sample preparation}

Dried powder of leunca herbs were purchased from Balai Besar Penelitian dan Pengembangan Tanaman Obat dan Obat Tradisional (B2P2TOOT), Indonesia. Dried powder was then extracted by maceration for 5 days with $70 \%$ ethanol. Collected filtrate was concentrated using rotary evaporator (Heidolph WB2000), then dissolved in Dimethyl Sulfoxide (DMSO) (Sigma). Both $5 \mathrm{mg} / \mathrm{ml}$ doxorubicin and extract solution were diluted in DMEM cell culture medium before being applied. DMSO was used as the co-solvent in dissolving LEE in DMEM culture medium.

\section{Chemicals}

Dulbecco's Modified Eagle Medium (DMEM) powder (Gibco), 10\% $\%{ }_{\mathrm{v}}$ Fetal Bovine Serum (FBS) (Gibco), and 10,000 units $/ \mathrm{ml}$ Penicillin-10,000 $\mu \mathrm{g} / \mathrm{ml}$ Streptomycin (Gibco) were used for cell culture medium. Cells were harvested using 25\% Tripsin EDTA (Gibco). For cytotoxicity assay, $10 \% \mathrm{v} / \mathrm{v}$ Sodium Dodecyl Sulphate (SDS) (Merck) dissolved in $0.1 \mathrm{~N} \mathrm{HCl}$ (Merck) as stopper reagent, and 3-[4,5-dimethyl thiazole-2-y(-2,5- diphenyl tetrazolium bromide)] (MTT) dissolved in PBS as MTT reagent were used.

\section{HeLa cells}

$\mathrm{HeLa}$ cells being used were from the collection of Cancer Chemoprevention Research Center (CCRC), Universitas Gadjah Mada. The cell line was a gift from Prof. Tatsuo Takeya, Nara Institute of Science and Technology (NAIST), Japan.

\section{Cytotoxicity and combinatorial assay}

MTT cytotoxicity assay was used to examine the effect of LEE alone and in combination with doxorubicin on HeLa cells.
$5 \times 10^{3} \mathrm{HeLa}$ cells/well was distributed into 96-well plate (Iwaki) and incubated in $37^{\circ} \mathrm{C}$ with $5 \% \mathrm{CO}_{2}$ (Heraeus) for 24 hours. In combinatorial assay, concentration of 5,50 , and $250 \mu \mathrm{g} / \mathrm{ml}$ for LEE and $100,250 \mathrm{nM}$ for doxorubicin were used. After 24 hours incubation, MTT reagent was applied, followed by 4 hours incubation. 10\% v/v SDS in $0.1 \mathrm{~N} \mathrm{HCl}$ as stopper reagent was then applied. Plate was then kept with protection from light overnight, continued with absorbance determination $(\lambda 595 \mathrm{~nm})$ using ELISA reader (Bio-Rad).

\section{Analysis}

The cells' viability was calculated based on the formula as follow:

$\%$ viability $=\frac{\text { absorbance of treated cellys-absorbance of control media }}{\text { absorbance of control celly-sbsobbance of control media }} \times 100 \%$

The cells' viability of LEE combined with doxorubicin treated cells then compared to LEE treated alone.

\section{RESULTS AND DISCUSSION}

Single and combinatorial treatment of LEE and doxorubicin on HeLa cells gave the viability shown in Table I, and being plotted in diagram (Fig. 1). It was shown that four concentration of combinations shows synergism on HeLa cells, represented with less cells' viability of combinatorial treatment compared to single treatment.

Cells' morphology after treatment was also observed (Fig. 2). Treatment of LEE or doxorubicin alone led to cells' morphological change pointed by white arrows, respectively (Fig. 2(b) and 2(c)). Combination of them caused more changes compared to single treated cells (Fig. 2(d)). While control cells showed no changing in cells' morphology representing cells' death (Fig. 2(a)). Hence, synergism of combinatorial treatment was observed. 
Table I. Cell viability (\%) of single and combinational treatment of LEE and doxorubicin on HeLa cells

\begin{tabular}{cccc}
\hline LEE concentration $(\boldsymbol{\mu g} / \mathbf{m l})$ & \multicolumn{3}{c}{ Doxorubicin $(\mathbf{n M})$} \\
\cline { 2 - 4 } & 0 & 100 & 250 \\
0 & 100 & 102.49 & 99.33 \\
5 & 110.47 & 107.98 & 92.68 \\
50 & 99.50 & 85.62 & 86.28 \\
250 & 64.51 & 65.84 & 46.97 \\
\hline
\end{tabular}

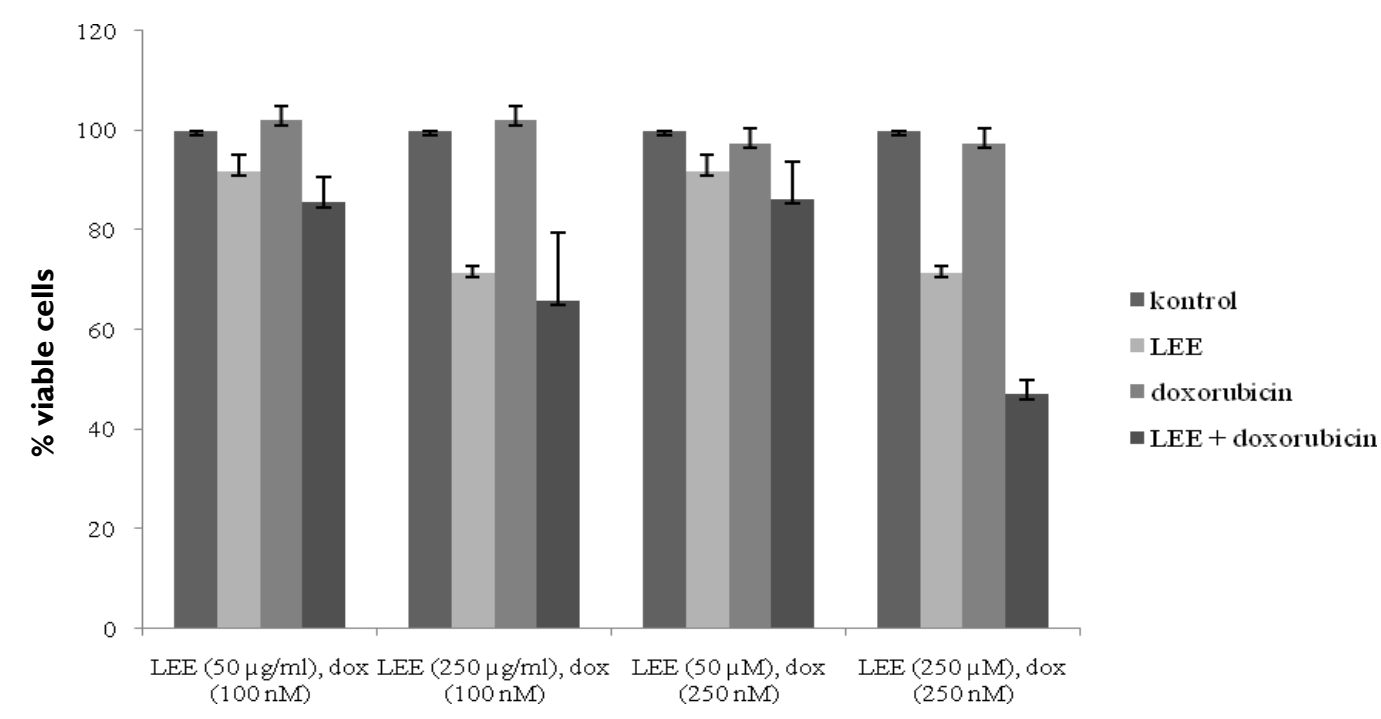

Figure I. Combinational effect of LEE and doxorubicin. Test were carried out by incubating $5 \times 10^{3} \mathrm{MCF}-7$ cells/well with concentration $50 \mu \mathrm{LEE} / \mathrm{ml}, 250 \mu \mathrm{LEE} / \mathrm{ml}$, and doxorubicin $100 \mathrm{nM}, 250 \mathrm{nM}$ for 24 hours. After 24 hourd, cell were added by MTT reagent to obtain the absorbance representing cell viability. Combination treatment of LEE $250 \mu \mathrm{g} / \mathrm{ml}$ and doxorubicin $250 \mathrm{nM}$ give optimal reduction of cell viability. 


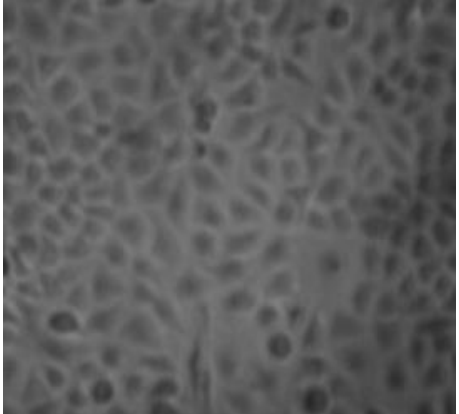

(a)

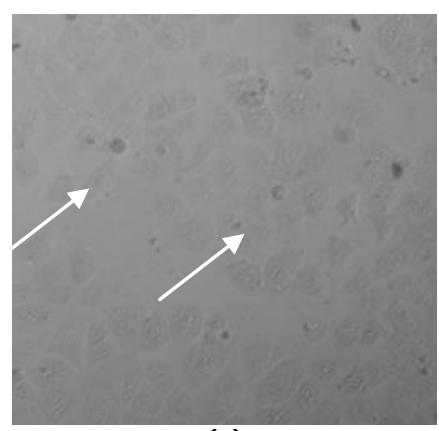

(c)

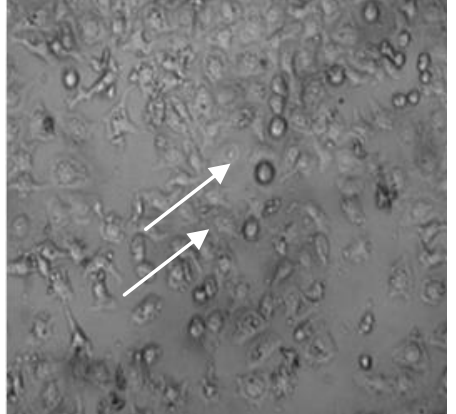

(b)

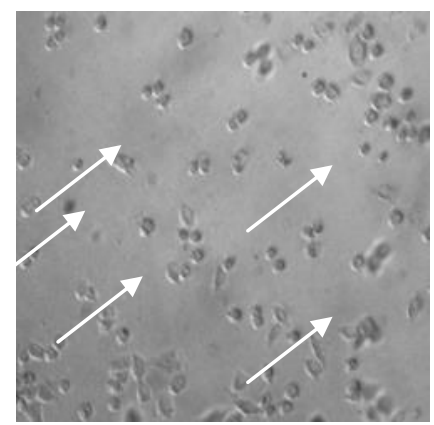

(d)

Figure 2. Combination of doxorubicin and LEE showed synergism on HeLa cells; (a) cell control; 24hours treatment of (b) $250 \mathrm{\mu g} / \mathrm{ml}$ LEE; (c) 250nMdoxorubicin; (d) 250nM doxorubicin in combination with $250 \mu \mathrm{g} / \mathrm{ml}$ LEE. Treatment of LEE and doxorubicin alone brought cells to death, shown by change in cells' morphology pointed by white arrows, respectively (b and c). Combination of them caused more cells' death compared to single treated cells (d), showing synergism. While control cells showed no change in cells' morphology (a). Observation was done by using inverted microscope at 300x magnification.

Leunca ethanolic extract alone is cytotoxic against $\mathrm{HeLa}$ cells with $\mathrm{IC}_{50} 227 \mu \mathrm{g} / \mathrm{mL}$ (Istiaji et al., 2010). When it is combined with doxorubicin, it performed synergistic effect. The cells' viability is decreasing compared to LEE treated cells, meaning that the combination gave inhibition of HeLa cells' growth. LEE may contain solanine and solamargine (Everist, 1974; Weller and Phipps, 1979). Solanine and $\beta$-2-solamargine suppress Bcl2 expression (Ji et al., 2008; Liu et al., 2004). Bcl2 is an antiapoptotic protein. Overexpression of $\mathrm{Bcl}-2$ prevented the efflux of cytochrome $\mathrm{c}$ from the mitochondria and the initiation of apoptosis (Yang et al., 1997). When it suppressed, cells will undergo apoptosis easier. Cytosolic cytochrome c will be larger when Bcl-2 is down regulated. This will lead to initiation of apoptosis (Yang et al., 1997). Liang et al. (2008) also proved that $\beta-2$ solamargine induced apoptosis through mitochondrial pathway, rendering the correlation between Bcl-2 suppression and apoptosis induction via classical pathway. The TNFRs induction on lung cancer cells (Liu et al., 2004) probably could be other mechanism on HeLa cells' growth inhibition. The molecular targeted protein of LEE should be determined briefly.

The combination of LEE and doxorubicin exhibited synergism on inhibition of HeLa cells' growth. To have the same number of cells' viability, we'll need less doxorubicin. This will lessenside effects as well as less resistance phenomenon found in cancer cells treated with chemotherapeutic agent (Kufe et al., 2003). Synergism of the combination possibly happened due to the ability of LEE to induce apoptosis by different mechanism with doxorubicin. Doxorubicin inhibits topoisomerase II activity (Potter and Rabinovitch, 2005), while LEE induces apoptosis via its solanine and solamargine activities. Further study needs to be conducted to determined molecular mechanism underlying this activity.

\section{CONCLUSION}

We can conclude that LEE has synergism activity when combined with doxorubicin on HeLa cells. 


\section{REFERENCES}

Anindyajati, Sarmoko, Putri, D.D.P., Hermawan, A. and Meiyanto, E., 2010, Combination of Solanumnigrum L., Herb Ethanolic Extract and Doxorubicin Performs Synergism on T47D Breast Cancer Cell Line, Indonesian Journal of Cancer Chemoprevention, I(2), 78-84.

Everist, S.L., 1974, Poisonous Plants of Australia, Angus and Robertson, Sydney.

Hu, K., Kobayashi, H., Dong, A., Jing, Y., Iwasaki, S. and Yao, X., 1999, Antineoplastic Agents III: Steroidal Glycosides from Solanumnigrum, PlantaMedica, 65(I), 3538.

Istiaji, R.P., Fitria, M., Larasati, Tjondro F., Maruti, A.A., Setyowati, E.P. and Meiyanto, E., 2010, Leunca (Solanumnigrum L.) Herbs Ethanolic Extract Increase Cytotoxic Activity of Cisplatin on Hela Cervical Cancer Cells, Indonesian Journal of Cancer Chemoprevention, I (I), 32-37.

Ji, Y.B.., Gao, S.Y., Ji, C.F. and Zhou, X., 2008, Induction of Apoptosis in HepG2 Cells by Solanine and Bcl-2 Protein, J. Ethnopharmacol, I I 5(2), 194-202.

Kufe, D.W., Pollock, R.E. and Weichselbaum, R.R., editors Hamilton (ON): BC Decker, 2003,
Combination Chemotherapy, Cancer Medicine $6^{\text {th }}$ edition, Holland-Frei.

Liang, C.H., Shiu, L.Y., Chang, L.C., Sheu, H.M., Tsai, E.M. and Kuo, K.W., 2008, Solamargine Enhances HER2 Expression and Increases the Susceptibility of Human Lung Cancer $\mathrm{H} 66 \mathrm{I}$ and $\mathrm{H} 69$ Cells to Trastuzumab and Epirubicin, Chem. Res. Toxicol., 2 I (2), 393-399.

Liu, L.F., Liang, C.H., Shiu, L.Y., Lin, W.L., Lin, C.C. and Kuo, K.W., 2004, Action of Solamargine on Human Lung Cancer Cells-Enhancement of the Susceptibility of Cancer Cells to TNFs, FEBS Lett., 577(I-2), 67-74.

Potter, A.J. and Rabinovitch, P.S., 2005, The Cell Cycle Phases of DNA Damage and Repair Initiated by Topoisomerase II-Targeting Chemotherapeutic Drugs, Mutation Research/Fundamental and Molecular Mechanisms of Mutagenesis, 572(I-2), 2744.

Weller, R.F. and Phipps, R.H., 1979, A Review of the Black Nightshade (Solanumnigrum L.), Protection Ecology, I, I 2 I-I39

Yang, J., Liu, X., Bhalla, K., Kim, C.N., Ibrado, A.M., Cai, J., Peng, T.I., Jones, D.P. and Wang, X., 1997, Prevention of Apoptosis by $\mathrm{Bcl}-2$ : Release of Cytochrome $\mathrm{C}$ from Mitochondria Blocked, Science, 275(5303), I I 29- I I 32. 